\title{
Use of Hearing Aids and Functional Capacity in Middle-Aged and Elderly Individuals
}

\author{
Juliana Carioli ${ }^{1} \quad$ Adriane Ribeiro Teixeira ${ }^{2}$ \\ 1 Specialization Course of Audiology, Universidade Federal do Rio \\ Grande do Sul, Porto Alegre, Rio Grande do Sul, Brazil \\ 2 Department of Developmental Psychology and Personality, \\ Universidade Federal do Rio Grande do Sul, Porto Alegre, Rio Grande \\ do Sul, Brazil
}

\begin{abstract}
Address for correspondence Adriane Ribeiro Teixeira, PhD, Department of Developmental Psychology and Personality, Universidade Federal do Rio Grande do Sul, Rua Ramiro Barcelos, 2600-Instituto de Psicologia da UFRGS, Porto Alegre, Rio Grande do Sul 90035003, Brazil (e-mail: adriane.teixeira@gmail.com).
\end{abstract}

\begin{abstract}
Introduction Hearing loss is among the sensory changes strongly associated with loss of functional capacity.

Objective It aims to determine whether the use of hearing aid contributes to the improvement of instrumental activities of daily living (IADL) for middle aged and elderly hearing-impaired individuals.

Methods This is a descriptive, longitudinal, and interventional study. We evaluated 17 subjects, 13 (76.5\%) female, aged between 58 and 96 years old (mean $77.1 \pm 10.4$ years). All were new users of hearing aids. Evaluation included social history, pure tone audiometry, and scale of IADL developed by Lawton and Brody. The subjects were presented daily life situations and were expected to respond if they could do them without assistance ( 3 points), partially assisted ( 2 points) or if they were unable to perform them (1 point). IADL was applied before the use of hearing aids adaptation and after a three- and six-month period of use.

Results Data analysis revealed that before the use of hearing aids the average score obtained by the subjects was $22.94 \pm 4.04$ points. Three months after beginning the use the average score was $23.29 \pm 4.12$ and after six months the average score was

Keywords

- elderly

- hearing loss

- hearing aids $23.71 \pm 3.69$ points. Statistical analysis revealed a significant difference between scores obtained before the use of hearing aids and six months post-fitting $\left(p=0.015^{*}\right)$ Conclusion The use of hearing aids among the subjects evaluated promoted positive changes in performing IADL, especially to using the telephone.
\end{abstract}

\section{Introduction}

Advances in health care, such as the discovery of diagnostic techniques and therapeutic methods effective in curing or controlling disease, can lead to increasing life expectancy. With these advances, elderly people are expected to maintain their functional capacity so that they remain autonomous and independent as long as possible. For such, it is of great importance to introduce health programs aimed at the pre- vention, early diagnosis, and treatment of chronic diseases and disabilities that arise over the years. ${ }^{1-6}$

As we age, there is a tendency toward chronic degenerative diseases that compromise the physical and mental functions of the individuals and ultimately lead to difficulties in daily activities or disability of the elderly to perform them. ${ }^{1-6}$

Currently it is said that health is measured through the ability of the individual to remain functionally independent and not due to the presence or absence of disease; the received

September 15, 2013

accepted

November 26, 2013

published online

February 28, 2014
DOI http://dx.doi.org/

10.1055/s-0034-1368136. ISSN 1809-9777.
Copyright $\odot 2014$ by Thieme Publicações License terms Ltda, Rio de Janeiro, Brazil

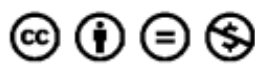


constraints brought by disability can cause more significant problems than the disease itself, as it can make patients dependent on their family and caregivers and can compromise their well-being and quality of life. ${ }^{7-10}$

The concepts for functional capacity are very similar. It is related to the degree of preservation of the individual to perform activities of daily living (ADL) and instrumental activities of daily living (IADL), so they can live independently. ${ }^{11,12}$

Functional capacity is evaluated in two aspects: basic ADL (i.e., the individual's ability to feed, bathe, and dress without help) and IADL, which evaluate more complex tasks, often related to individuals' social engagement, such as shopping, answering the telephone, and using means of transportation. ${ }^{13}$

Hearing loss is one of the most frequent and disabling sensory changes, not only negatively affecting the elderly socially and emotionally but also affecting their quality of life. ${ }^{14-17}$ It is believed that hearing loss is strongly associated with loss of functional capacity, ${ }^{18,19}$ which explains the importance of this study.

Thus, the present study aimed to examine whether the use of hearing aids improves functional capacity for IADL for hearing-impaired middle-aged and elderly individuals.

\section{Methods}

The research is a descriptive, longitudinal, and interventional study. The population comprised 17 individuals, of both genders, between 58 and 96 years old (mean $77.1 \pm 10.4$ years).

Inclusion criteria were: individuals from 40 years old (which is considered the beginning of middle age), ${ }^{20}$ new users of hearing aids with bilateral hearing loss, and participation in all phases of the research. Exclusion criteria were: not signing the informed consent form (ICF) and history of cognitive, neurologic, and/or psychiatric disorders. For participants who met the inclusion criteria, we presented the objectives of the research, and all participants signed ICF.

First, the individuals were submitted to audiological evaluation, with pure tone audiometry performed in a soundproof booth and with tone thresholds by air (from 250 to $8,000 \mathrm{~Hz}$ ) and bone (500 to $4,000 \mathrm{~Hz}$ ) measured using an Interacoustics audiometer model AD-229, Denmark.

To classify the degree of hearing loss, we used the average of the hearing thresholds by air at 500, 1,000, 2,000, and $4,000 \mathrm{~Hz}$, according to the World Health Organization. ${ }^{21}$ Mean values between $-10 \mathrm{dBHL}$ (decibel hearing level) and $25 \mathrm{dBHL}$ indicate that the person has normal hearing thresholds; between 26 and $40 \mathrm{dBHL}$, mild hearing loss; between 41 and $60 \mathrm{dBHL}$, moderate hearing loss; between 61 and 80 $\mathrm{dBHL}$, severe hearing loss; above $81 \mathrm{dBHL}$, profound hearing loss. For this study we considered the mean of the better ear.

This study was developed in three stages. In the first stage of evaluation, the procedures were as follows: we applied social history developed (anamnesis) especially for this study, containing demographic and hearing history. Furthermore, we used a questionnaire created by Lawton and Brody (1969), ${ }^{22}$ which measured the ability of the individual to develop IADL. Through this, we evaluated the functional capacity (i.e., the degree of independence of these individuals in everyday activities, such as using the telephone, preparing meals, managing finances, commuting by means of public transportation, cleaning the house, going shopping, among others).

These issues were assessed using nine items where the patient had three response options: "able without assistance" (score 3), "able with partial assistance" (score 2), and "unable" (score 1). The maximum achievable score in the evaluation was 27 points, which corresponds to maximum independence, and the minimum achievable score was 9 points, meaning maximum dependency.

After completing the questionnaire, hearing aid(s) indicated for each subject were selected and tested. All subjects were fitted with hearing aid(s) with digital technology, with nonlinear amplification. Nine (52.9\%) participants used bilateral hearing aids and 8 (47.1\%) used a single one.

The second stage of the research was initiated 3 months after beginning usage of hearing aid(s); the patient was contacted by telephone and asked to attend a meeting reviewing their hearing aid(s). At the hearing center, the patient answered a questionnaire evaluating functional capacity.

In the third stage, which began 6 months after beginning usage of hearing aid(s), patients again answered the questionnaire for assessing functional capacity.

The project was submitted to and approved by the Research and Ethics Committee of the institution (no. 212439). The rights regarding confidentiality, anonymity, and withdrawal of participation without prejudice to any treatments that were being performed were assured.

Data were both quantitative and descriptive statistically analyzed. To evaluate the performance of individuals for the task at each stage, descriptive statistical analysis was performed and then the nonparametric Friedman test was used. The total score was used to assess the overall performance of the individual (considering performance on all tasks). To compare the total score between steps and descriptive statistics, analysis of variance for repeated measures was performed.

\section{Results}

The sample consisted of 17 subjects, 13 women (76.5\%) and 4 men (23.5\%). Although the inclusion criteria defined that the minimum age would be 40 years, the sample consisted of subjects aged between 58 and 96 years (mean $77.1 \pm 10.4$ years). The other characteristics are shown in - Table 1. With regard to education, most individuals had incomplete primary education (76.5\%). Of the population, $76.4 \%$ had moderate hearing loss, $11.8 \%$ presented mild hearing loss, and $11.8 \%$, severe hearing loss. For this classification, we took into account the best ear. All subjects were fitted with hearing aids with digital technology, with nonlinear amplification. Nine $(52.9 \%)$ participants use bilateral hearing aids and 8 (47.1\%), monoaural aids.

Data on the ability of the elderly to perform IADL for the three stages of the research are described in -Table 2.

- Table 3 shows the total score obtained by participants in the three stages of the research; a significant increase in the 
Table 1 Characteristics of the sample regarding demographic, social, and audiological variables

\begin{tabular}{|l|l|l|}
\hline Variables & $n$ & $\%$ \\
\hline Gender & \multicolumn{2}{l|}{} \\
\hline Male & 4 & 23.5 \\
\hline Female & 13 & 76.5 \\
\hline Education & 1 & 5.9 \\
\hline Illiterate & 2 & 11.8 \\
\hline Primary school & 2 & 76.5 \\
\hline Incomplete primary school & 13 & 5.9 \\
\hline Higher education & 1 & 11.8 \\
\hline Degree of hearing loss & \multicolumn{2}{|l}{} \\
\hline Mild & 2 & 76.4 \\
\hline Moderate & 13 & 11.8 \\
\hline Severe & 2 & 47.1 \\
\hline Hearing aid fitting & \multicolumn{2}{|l}{} \\
\hline Monoaural & 9 & 52.9 \\
\hline Binaural & 9 & \\
\hline
\end{tabular}

degree of independence of individuals was found comparing the first and third stages $(p=0.015)$.

- Table 4 shows the evolution in the use of the telephone in the three stages of the research. There was a significant difference $(p=0.011)$ between at least two of the three stages in the degree of independence in using the telephone. Although it was not possible to identify the difference in multiple comparison tests, the lowest observed $p$ value $(p=0.123)$ indicates that this difference is probably between the level of independence of the first and third stage, with the third stage being the higher level of independence.

\section{Discussion}

We observed among the participants of the study a higher ratio of women (76.5\%), which did not differ from other studies. ${ }^{6,23}$ Although the scientific literature shows that men are more affected by hearing loss, ${ }^{24}$ data show that women seek more health services. ${ }^{25}$ In addition, data from the 2010 population census in the country and the literature in the field of gerontology show that the majority of Brazilian individuals in the age range studied are women. ${ }^{26-28}$ This fact is known as "feminization of aging" and is corroborated by previous studies, ${ }^{6,23}$ and it should be taken into consideration for appraisal, diagnosis, and treatment of hearing services, which should be prepared to meet, in most cases, female subjects with specific characteristics, needs, and requirements.

A low level of education was expected by the researchers because many participants were elderly. This population, according to the 2010 census, has low levels of education because it had no opportunity to attend school in the life stage considered appropriate. ${ }^{26,29,30}$ Furthermore, it should be stressed again that many of the sample were women. Thus, until a few years ago, few women attended schools, and many who abandoned their studies as they finished the initial grades to devote themselves to learning housework.

The degree of hearing loss observed in most cases is compatible with that caused by aging. Previous studies indicate that the majority of the elderly had mild to moderate hearing loss, which corroborates the results of this research and was expected by researchers due to the age range of the sample components. ${ }^{31,32}$ Although all subjects presented bilateral hearing loss, approximately half of the individuals (47.1\%) acquired only one hearing aid. This could be explained by the fact that the purchase was made by the subjects of research, using their own financial resources. Thus, in many cases, although there was an indication of binaural fitting of hearing aids, financial issues, aesthetics, manual dexterity, auditory processing, or asymmetrical hearing loss led to monaural fitting. ${ }^{33}$ This is quite common when analyzing the purchase of hearing aids in private hearing centers, which has been reported in other studies. ${ }^{34,35}$

As previously described, the functional capacity is strongly related to the presence of some diseases and disabilities. Studies demonstrate that there is an association between hearing loss and the lack of autonomy of patients. ${ }^{1,10,36}$ Thus, we expected a low autonomy of the individuals to perform IADL in the first stage of the study, an evolution occurring after fitting (steps 2 and 3). The analysis of data contained in - Table 2, however, showed that compared with the ability to carry out IADL between the three stages, the only task in which there was significant change was the ability to use the telephone ( $p=0.011)$. The change was so evident that it was able to give a significant difference in scores between the three stages of the study (-Table 3 ).

Most individuals could perform adequately and effectively the investigated IADL, contrary to what was expected by the evaluators because most of the subjects had hearing loss and low levels of education. This finding contradicts other studies, whose results indicated that the low level of education and hearing loss negatively influenced the autonomy of the elderly. ${ }^{1,6,10,37}$

Most of the subjects had hearing loss from mild to moderate in the better ear, which can make communication difficult through the use of the phone. To carry out the other activities, however, the individual may resort to communication strategies, such as lipreading and requesting repetition of phrases. In addition, some activities investigated by the instrument, such as shopping, ironing, controlling remedies and finance, for example, are more closely related to cognitive and motor activity and may not be influenced by the presence of mild to moderate hearing loss.

Data in - Table 4 confirm the change observed between the three evaluations with regard to the use of the phone. The analysis suggests that the change in the behavior of the subjects occurred between steps 1 and 3 of the research. The greater autonomy in the use of the telephone does not confirm previous studies that reported on new hearing aid users whose main complaint was difficulty using the telephone. ${ }^{38-40}$ The studies cited, however, are prior to 2010 , before hearing aid resources facilitating the use of 
Table 2 Ability to perform instrumental activities of daily living during the three stages of the research

\begin{tabular}{|c|c|c|c|c|c|c|c|}
\hline \multirow[t]{2}{*}{ Task } & \multicolumn{2}{|c|}{ Stage 1} & \multicolumn{2}{|c|}{ Stage 2} & \multicolumn{2}{|c|}{ Stage 3} & \multirow[t]{2}{*}{$p$ value } \\
\hline & $n$ & $\%$ & $n$ & $\%$ & $n$ & $\%$ & \\
\hline Use the telephone: & & & & & & & 0.011 \\
\hline Unable & 8 & 47.1 & 5 & 29.4 & 2 & 11.8 & \\
\hline Able without assistance & 9 & 52.9 & 12 & 70.6 & 15 & 88.2 & \\
\hline Commute to distant sites: & & & & & & & $>0.999$ \\
\hline Unable & 3 & 17.6 & 3 & 17.6 & 3 & 17.6 & \\
\hline Able with partial assistance & 5 & 29.4 & 5 & 29.4 & 5 & 29.4 & \\
\hline Able without assistance & 9 & 52.9 & 9 & 52.9 & 9 & 52.9 & \\
\hline Shop: & & & & & & & $>0.999$ \\
\hline Able with partial assistance & 4 & 23.5 & 4 & 23.5 & 4 & 23.5 & \\
\hline Able without assistance & 13 & 76.5 & 13 & 76.5 & 13 & 76.5 & \\
\hline Prepare meals: & & & & & & & $>0.999$ \\
\hline Unable & 1 & 5.9 & 1 & 5.9 & 1 & 5.9 & \\
\hline Able with partial assistance & 1 & 5.9 & 1 & 5.9 & 1 & 5.9 & \\
\hline Able without assistance & 15 & 88.2 & 15 & 88.2 & 15 & 88.2 & \\
\hline Clean the house: & & & & & & & $>0.999$ \\
\hline Unable & 2 & 11.8 & 2 & 11.8 & 2 & 11.8 & \\
\hline Able without assistance & 15 & 88.2 & 15 & 88.2 & 15 & 88.2 & \\
\hline Handicraft: & & & & & & & $>0.999$ \\
\hline Unable & 4 & 23.5 & 4 & 23.5 & 4 & 23.5 & \\
\hline Able with partial assistance & 3 & 17.6 & 3 & 17.6 & 3 & 17.6 & \\
\hline Able without assistance & 10 & 58.8 & 10 & 58.8 & 10 & 58.8 & \\
\hline Wash and iron clothes: & & & & & & & $>0.999$ \\
\hline Unable & 3 & 17.6 & 3 & 17.6 & 2 & 11.8 & \\
\hline Able with partial assistance & & & & & 1 & 5.9 & \\
\hline Able without assistance & 14 & 82.4 & 14 & 82.4 & 14 & 82.4 & \\
\hline Take medicines: & & & & & & & $>0.999$ \\
\hline Able with partial assistance & 4 & 23.5 & 4 & 23.5 & 4 & 23.5 & \\
\hline Able without assistance & 13 & 76.5 & 13 & 76.5 & 13 & 76.5 & \\
\hline Manage finances: & & & & & & & $>0.999$ \\
\hline Able with partial assistance & 10 & 58.8 & 10 & 58.8 & 10 & 58.8 & \\
\hline Able without assistance & 7 & 41.2 & 7 & 41.2 & 7 & 41.2 & \\
\hline
\end{tabular}

telephone were available. Moreover, it should be pointed out that in addition to these resources, all subjects in the research sample received specific guidelines from the pathologist responsible for selecting and fitting hearing aids. In the fitting process, individuals and their families should be targeted, and the use of telephone and other auxiliary equipment should be one of the items addressed. ${ }^{41}$

Thus, considering the test scores (especially with regard to the use of the telephone) and the time of use of hearing aids by the subjects, it appears that there was a gradual improvement

Table 3 Overall score per assessment stage

\begin{tabular}{|l|l|l|l|l|l|l|}
\hline & $\boldsymbol{n}$ & Mean & Standard deviation & Median & Minimum & Maximum \\
\hline Overall score (stage 1) & 17 & 22.94 & 4.04 & 24 & 12 & 27 \\
\hline Overall score (stage 2) & 17 & 23.29 & 4.12 & 25 & 12 & 27 \\
\hline Overall score (stage 3) & 17 & 23.71 & 3.64 & 25 & 14 & 27 \\
\hline
\end{tabular}

Note: $p=0.015$ from stage 1 to stage 3 . 
Table 4 Changes in use of the telephone in the three stages of the research

\begin{tabular}{|l|l|l|l|}
\hline & $\begin{array}{l}\text { Stage 1 } \\
(\mathbf{\%})\end{array}$ & $\begin{array}{l}\text { Stage 2 } \\
(\mathbf{\%})\end{array}$ & $\begin{array}{l}\text { Stage 3 } \\
\mathbf{( \% )}\end{array}$ \\
\hline Unable & 47.1 & 29.4 & 11.8 \\
\hline Able without assistance & 52.9 & 70.6 & 88.2 \\
\hline
\end{tabular}

Note: $p=0.011$ from stage 1 to stage 3 .

in auditory skills and speech recognition due to the new use of amplification. ${ }^{42}$ These findings corroborate other studies describing the acclimatization period starting from week 6 of amplification. $^{43,44}$ In 2002, 134 elderly in the first year of adjustment of hearing prosthesis showed more significant changes between the first and sixth months of use. ${ }^{44}$ Thus, we can confirm the importance of the intervention with the use of hearing aids in middle-aged adults and seniors.

\section{Conclusion}

The analysis of the results showed that the use of hearing aid (s) improved functional capacity for IADL in the individuals evaluated, especially in using the telephone.

\section{References}

1 Rosa TEC, Benício MHDA, Latorre MR, Ramos LR. Determinant factors of functional status among the elderly. Rev Saude Publica 2003;37(1):40-48

2 Guedes JM, Silveira RCR. Análise da capacidade funcional da população geriátrica institucionalizada na cidade de Passo Fundo-RS. RBCEH 2004;1(37):10-21

3 Costa EC, Nakatani AYK, Bachion MM. Capacidade de idosos da comunidade para desenvolver Atividades de Vida Diária e Atividades Instrumentais de Vida Diária. Acta Paul Enferm 2006;19(1): 43-45

4 Alves LC, Quinet Leimann BC, López Vasconcelos ME, et al. The effect of cronic diseases on functional status of the elderly living in the city of São Paulo, Brazil. Cad Saude Publica 2007;23(8): 1924-1930

5 Alves LC, Leite IC, Machado CJ. The concept and measurement of functional disability in the elderly population: a literature review. Cienc Saude Coletiva 2008;13(4):1199-1207

6 Alves MJM, Ribeiro LC, Milane JL, Almeida AM. Perfil da Capacidade Funcional do Idoso. Annals of the XVI National Meeting of Population Studies; 2008. Available at http://www.abep.nepo.unicamp.br/encontro2008/docspdf/ABEP2008_1534.pdf. Accessed on January 29, 2014

7 Bonardi G, Souza VBA, Moraes JFD. Incapacidade Funcional e idosos. Sci. Med 2007;17(3):138-144

8 Lachs MS, Feinstein AR, Cooney LM Jr, et al. A simple procedure for general screening for functional disability in elderly patients. Ann Intern Med 1990;112(9):699-706

9 Veras RP. País Jovem com Cabelos Brancos: a saúde do idoso no Brasil. Rio de Janeiro, Brazil: Relume Dumará; 1994

10 Schneider RH, Marcolin D, Dalacorte RR. Avaliação funcional de idosos. Sci. Med 2008;18(1):4-9

11 Ribeiro RCL, Silva AIO, Modena CM, Fonseca MC. Capacidade Funcional e qualidade de vida de idosos. Estud Interdiscip Envelhec 2002;4:85-96
12 Ramos LR. Determinant factors for healthy aging among senior citizens in a large city: the Epidoso Project in São Paulo. Cad Saude Publica 2003;19(3):793-797

13 Espejo Espejo J, Martínez de la Iglesia J, Aranda Lara JM, et al. Evaluative cycle of the process of a full geriatric assessment programme run by a Health Centre. Aten Primaria 1997;20(1):3-11

14 Russo ICP. Intervenção audiológica no idoso. In: Ferreira LP, ed. Tratado de fonoaudiologia. São Paulo, Brazil: Roca; 2004:585-596

15 Mattos LC, Veras RP. A prevalência da perda auditiva em uma população de idosos da cidade do Rio de Janeiro: um estudo seccional. Rev Bras Otorrinolaringol (Engl Ed) 2007;73(5): 654-659

16 Veras RP, Mattos LC. Audiology and aging: literature review and current horizons. Braz J Otorhinolaryngol 2007;73(1):128-134

17 Ribeiro LCC, Alves PB, Meira EP. Percepção do idoso sobre as alterações fisiológicas do envelhecimento. Ciênc Cuid Saúde 2009;8(2):220-227

18 Santos LD, Salmela LFT, Lelis FO, Lobo MB. Eficácia da Atividade Física na manutenção do desempenho funcional do idoso: revisão de literatura. Revista Fisioter Bras 2001;2(3):169-176

19 Ramos MP. Apoio Social e saúde entre idosos. Sociologias 2002; 4(7):156-175

20 Duarte CP, Santos CL, Gonçalves AK. A concepção de pessoas de meia-idade sobre saúde, envelhecimento e atividade física como motivação para comportamentos ativos. Rev Bras Cienc Esporte 2002;23(3):35-48

21 Organização Mundial da Saúde. WHO/PDH/97.3 Geneva, Switzerland: WHO; 1997

22 Lawton MP, Brody EM. Assessment of older people: self-maintaining and instrumental activities of daily living. Gerontologist 1969; 9(3):179-186

23 Rogers RG, Rogers A, Belanger A. Active life among the elderly in the United States: multistate life-table estimates and population projections. Milbank Q 1989;67(3-4):370-411

24 Mattos LC, Veras RP. The prevalence of hearing loss in na elderly population in Rio de Janeiro: a cross sectional study. Braz J Otprhinolaryngol 2007;73(5):654-659

25 Gomes R, Nascimento EF, Araújo FC. Why do men use health services less than women? Explanations by men with low versus higher education. Cad Saude Publica 2007;23(3):565-574

26 Instituto Brasileiro de Geografia e Estatística. Brasília (DF), Brazil; IBGE: 2010. Available at http://www.ibge.gov.br. Accessed November 11, 2013

27 Salgado CDS. Mulher idosa: a feminização da velhice. Estud Interdiscip Envelhec 2002;4:7-19

28 Nicodemo D, Godoi MP. Juventude dos anos 60-70 e envelhecimento: estudo de casos sobre feminização e direitos das mulheres idosas. Rev Ciênc Ext 2010;6(1):40-53

29 Souza MMC. O analfabetismo no Brasil sob o enfoque demográfico. Textos para discussão no. 639. Available at: http://www.ipea.gov.br/ portal/images/stories/PDFs/TDs/td_0639.pdf. Accessed November 11, 2013

30 Mafra SCT, Silva EP, Fonseca ES, Almeida AV, Freitas NC. O envelhecimento nas diferentes regiões do Brasil: uma discussão a partir do censo demográfico de 2010. Anais do VI Workshop de Análise Ergonômica do Trabalho, III Encontro mineiro de Estudos em Ergonomia e VIII simpósio do Programa de Educação Tutorial em Economia Doméstica-Envelhecimento: como pensar o trabalho, a sociedade e as cidades? Available at: http://www.ded.ufv. br/workshop/docs/anais/2013/Simone\%20Caldas\%20Tavares\% 20Mafra\%20-\%20\%20\%20\%20\%20\%20Tem\%C3\%A1 tica\%20Envelhecimento.pdf. Accessed November 11, 2013

31 Gardner M, Slenkovich NG. Disacusia neurossensorial. In: Jafek BW, Murrow BW, eds. Segredos em Otorrinolaringologia. Porto Alegre, Brazil: Artmed; 2006

32 Samelli AG, Negretti CA, Ueda KS, Moreira RR, Schochat E. Comparing audiological evaluation and screening: a study on presbycusis. Braz J Otorhinolaryngol 2011;77(1):70-76 
33 Almeida K, Iorio MCM. Próteses Auditivas: fundamentos teóricos e aplicações clínicas. São Paulo, Brazil: Lovise; 2003

34 Moura LOS, Iorio MCM, Azevedo MF. The efficacy of hearing aids on diminishing or eliminating tinnitus. Braz J Otorhinolaryngol 2004; 70(5):624-631

35 Zandavalli MB, Christmann LS, Garcez VRC. Rotina de procedimentos utilizados na seleção e adaptação de aparelhos de amplificação sonora individual em centros auditivos na cidade de Porto Alegre, Brasil-RS. Rev CEFAC 2009;11(Suppl 1):106-115

36 Gopinath B, Schneider J, McMahon CM, Teber E, Leeder SR, Mitchell P. Severity of age-related hearing loss is associated with impaired activities of daily living. Age Ageing 2012;41(2): 195-200

37 Fiedler MM, Peres KG. Functional status and associated factors among the elderly in a southern Brazilian city: a population-based study. Cad Saude Publica 2008;24(2):409-415

38 Magalhães FF, Mondelli MFCG. Assessment of hearing aids users' satisfaction - systematic review. Rev CEFAC 2011;13(3):552-558
39 Veiga LR, Merlo ARC, Mengue SS. Satisfação com a prótese auditiva na vida diária em usuários do Sistema de Saúde do Exército. Rev Bras Otorrinolaringol (Engl Ed) 2005;71(1):67-73

40 Fialho IM, Bortoli D, Mendonça GG, Pagnosim DF, Scholze AS. Percepção de idosos sobre o uso de AASI concedido pelo Sistema Único de Saúde. Rev CEFAC 2009;11(2):338-344

41 Geraldo T, Ferrari DV, Bastos BG. Orientação ao usuário de prótese auditiva: retenção da informação. Arq Int Otorrinolaringol 2011; 15(4):410-417

42 Munro KJ, Lutman ME. The effect of speech presentation level on measurement of auditory acclimatization to amplified speech. J Acoust Soc Am 2003;114(1):484-495

43 Almeida K. Avaliação dos resultados da intervenção. In: Almeida K, Iório MCM, eds. Próteses Auditivas: fundamentos teóricos e aplicações clínicas. 2nd ed. São Paulo, Brazil: Lovise; 2003:357-379

44 Humes LE, Wilson DL, Barlow NN, Garner C. Changes in hearing-aid benefit following 1 or 2 years of hearing-aid use by older adults. J Speech Lang Hear Res 2002;45(4):772-782 